\title{
The MENA Region - An Optimal Currency Area? Evaluating its Stability by Taylor-Rule Derived Stress Tests
}

\author{
Mouchera Karara*
}

\author{
German University in Cairo, Faculty of Management Technology, Egypt
}

\begin{abstract}
The European currency union with the EURO as its common currency is the most persistent and largest monetary union to date. At the beginning, it has attracted a lot of attention to the concept of monetary unions; yet, it has recently signaled a lot of warnings around the concept that requires careful studying prior to any duplication attempt. This paper aims at identifying potential currency unions in the MENA region based on interest rates' similarity as one of the aspects that affect a monetary union's success. To assess their sustainability, the optimal interest rates (Taylor rates) of the members of each potential union is estimated and used to calculate a stress level index. The sample used in this study consists of eleven countries where Taylor rates were calculated using data from 1998 to 2008 . The stress test results provide a clear result: Two monetary sub-unions, namely the Saudi Arabia - Kuwait union and the Mashreq union (Jordan, Egypt and Syria), are found to have relatively low stress levels and high benefits from a common currency. In contrast, a large MENA union would suffer from very high stress levels and only modest advantages of a common currency.
\end{abstract}

Keywords: Monetary union, MENA, Mashreq, GCC, stress analysis, economic integration, potential unions, interest rates.

\section{INTRODUCTION}

From 1947 to 2000, the number of countries in the world increased from 76 to 193 . With few exceptions, each of these countries has its own currency that is used not only as a medium of exchange but also as a form of identification whereby each country tries to reflect its unique identity, culture and history. Nevertheless, globalization has been a powerful trend in shaping world trade, allowing a massive increase in the volume of world transactions and thus cost associated to it. In an attempt to limit this rising currency exchange cost, some countries adopted the currency of their main trading partners and either stopped the circulation of their own currencies or used it along their newly adopted currency (also known as "Dollarization"). Consequently, dollarization created only few dominating currencies in the world today namely; US Dollar, Euro and Japanese Yen (Cohen 2003: 275f, Alesina \& Barro 2002: 409, Mundell 2000: 223). The rise of the Euro as a dominating currency came through the monetary unification of European countries. European countries were able to play a highly significant role in world economy, hence benefited from globalization and at the same time continued to reflect their unique identity through their adoption of a common currency.

European countries have sought unification since 1979 , starting at the level of trade integration and

*Address correspondence to this author at the German University in Cairo, Faculty of Management Technology, Egypt;

E-mail: mouchera.karara@hotmail.com escalating it to the level of monetary integration -also known as currency unions. The Euro experience attracted a lot of attention to the concept of monetary unions which entails the adoption of a single currency by a group of countries and a single monetary policy setting of interest rates and determining the level of money supply by the union's central bank. The European Monetary Union (EMU) was realized in 1999 among a group of European countries with the Euro as its common currency and today marks as one of the strongest currencies of the world despite its recent introduction. The establishment of the European currency union has repositioned European countries in the world, providing its countries -which have increased from eleven to eighteen- with more economic and political influence through the power of collective bargaining (Krugman \& Obstfeld 2006: 551).

Based on the European experience and the monetary union's ability to empower its countries internally and externally, a research on the plausibility of a currency union in the MENA region is motivated. Despite the challenges that the Euro-zone has recently faced, it is still able to survive and achieve its economic and strategic goals. Such an experience may be worth duplication in other parts of the world only after careful examination starting with the basics of a monetary union that is; a single monetary policy. It is also important to highlight that the MENA countries and the European countries are quite different with respect to the level of development both politically and economically, hence, the EU is used as an example or a bench mark in some cases. The MENA countries are 
highly diversified and endowed with numerous human, capital and natural resources that are not fully utilized. Thus, a monetary union as a form of integration that promotes development is being studied to investigate opportunities of efficient resource utilization in the region. Previous research has mainly focused on the evaluation of a monetary union in the MENA region through the analysis of the countries' macroeconomic variables such as; inflation rates, GDP levels, volume of trade and economic structures (Laabas \& Limam 2002, Wynne 2008, Richter 2012, Sturm \& Siegfried 2005). All these are integral aspects in the evaluation of currency unions in the MENA region; however, an evaluation of the monetary aspect is very poorly tackled. It is important to assess the behavior of these countries from a monetary aspect as they will be operating under a single monetary system.

The aim of this paper is to identify potential currency unions in the MENA region and assess the degree of their sustainability through examining the similarity in their interest rates. The empirical analysis conducted in this paper follows the methods adopted by Sturm \& Wollmershaeuser (2008), Flaig \& Wollmershaeuser (2007) and Moons \& Poeck (2008). Interest rates are calculated using the Taylor rule which are then compared to determine potential country groupings. Sustainability of each union is determined by measuring the stress level in a union; which is the difference between the countries' independently set interest rates and the area-wide interest rate. The higher the difference, the higher the level of stress will be and the lower the degree of the union's sustainability. Accordingly, it is hypothesized that countries with similar interest rates (low stress level) qualify for the formation of a currency union that is sustainable on the long-run.

The paper consists of four main sections; the first section titled "Theoretical Background" explains the concept of currency unions, the main motive behind the establishment of currency unions and highlights the fundamentals of the optimal currency area theory and its criteria. Following, in the second section titled "MENA countries: Characteristics and Interrelations", MENA countries interrelations are discussed under the light of the OCA criteria. The methodology adopted in this paper is presented in the third section with a detailed description of the sample and data used as well as the procedures followed in conducting the stress analysis. Empirical results are presented in the fourth section "Results" along with results discussion. Finally, a conclusion is provided at the end of this paper that focuses on the main conclusions, findings of this research, prospects for future research and limitations.

\section{THEORETICAL BACKGROUND}

\subsection{Currency Unions and Reasons behind their Establishment}

A currency union is formed when two or more countries abandon their national currencies and agree to adopt a single currency. Countries in a currency union do not only abandon their national currencies; they also abandon their monetary sovereignty to the union's central bank that determines a unified monetary policy for all countries in the union. Thus, the term monetary union is used interchangeably with currency union to indicate the adoption of a single monetary policy. The European Monetary Union (EMU) is a wellknown example of an established currency union (Mundell 1961: 658, Krugman \& Obstfeld 2006: 571, Cohen 2003: 276).

Generally speaking, the establishment of currency unions follows the rationale of the famous motto "united we stand, divided we fall". The reasons behind the formation of currency unions can be summarized into two main reasons. First, unification fuels its countries with more political and economic power on the international level. Second, a union fosters economic integration among its members leading to more economic development and growth. In other words, currency unions help in better serving its countries' external interests in the international world and internally improve its economic welfare. For instance, the European currency union has been established to voice its countries' economic and political interests, especially against more sizeable and powerful economic powers such as the United States of America. According to CIA 2011 estimates, the European Union's GDP (PPP) with all its current 27 members is $2 \%$ higher than the United States' GDP (PPP), which emphasizes the importance of the union in making the European countries comparable to the United States. In addition, the Euro has become the second most important currency in the world after the US Dollar. Hence, it is argued that currency unions are mainly established for political reasons rather than economic ones, i.e. to benefit from higher political and economic influence through the power of collective bargaining (Krugman \& Obstfeld 2006: 550, Mundell 2000: 223, Miles 2006: 414, Cohen 2003: 277f, Rockoff 2000: 4). 


\subsection{Optimal Currency Areas (OCA) and their Criteria}

The optimal currency area theory is an integral part in the foundation and spread of currency unions as a concept. The theory of optimal currency area was first introduced by Mundell (1961). Then, it was further developed by Mckinnon (1963) and Kenen (1969). A currency area is defined to be optimum when the net benefit to the countries involved in the establishment of a currency union outweighs the costs. In other words, an area becomes an optimal currency area when the choice of the establishment or entrance of/to a currency union puts the countries involved at an advantage compared to the status quo (Beetsma \& Giuliodori 2010: 605, Mckinnon 2004: 347, Ricci 1997: 5, Rockoff 2000: 4, Miles 2006: 412).

According to the OCA theory and literature, there are five criteria that are considered to be prerequisites to the establishment of a currency union. The five criteria are; degree of economic integration, degree of asymmetry of shocks, degree of labor mobility and wage flexibility, degree of economic production diversity, and fiscal integration and political unification. In the next section, the characteristics and interrelations of the MENA countries will be discussed through these five criteria. This discussion will also help in qualitatively assessing the potential of the establishment of a currency union in the MENA region.

\section{MENA COUNTRIES: CHARACTERISTICS AND INTERRELATIONS}

MENA stands for Middle East and North Africa group of countries. According to the World Bank definition of the MENA region, it includes twenty countries, namely; Algeria, Bahrain, Djibouti, Egypt, Iran, Iraq, Jordan, Kuwait, Lebanon, Libya, Malta, Morocco, Oman, Qatar, Syria, Tunisia, United Arab Emirates (UAE), Kingdom of Saudi Arabia (KSA), Yemen and Palestine. Six percent of the world population (355 million) lives in MENA countries, which is almost equivalent to the population size of the European Union. Economic activity in MENA countries focuses mainly on primary activities with a low-degree of diversification that could be classified into; agriculture, light manufacturing or oil extraction activities, yet, these activities are very weak for sustainable economic prosperity in the region and for intra-trade as will be discussed (Dervis et al. 1998: 3, The World Bank 2012, El-Erian et al. 1996: 3-7).

\subsection{Intra-Trade}

According to the OCA theory, countries that are more linked together via trade will benefit more from the establishment of a currency union. If two countries do not trade together at all or their volume of trade is relatively very small to their volume of trade with other countries, in such a case, the risk from exchange rate fluctuations is absent or negligible to justify the establishment of a currency union. Yet, it has been proven that currency unions facilitate economic integration. Thus, currency unions have the ability to foster trade relations which makes such a criteria both a prerequisite and outcome of currency unions (Mundell 1961: Miles 2006: 414, Mckinnon 2004: 346, Laabas \& Limam 2002: 5f, Bacha 2008: 516, Krugman \& Obstfeld 2006: 538-565, Ricci 1997: 33, Frankel \& Rose 1996: 4).

With respect to trade relations, MENA region could be divided into three distinct sub-regions based on geographic proximity, historical and cultural ties. The three groups are; Maghreb countries, Mashreq countries and GCC countries. Maghreb countries include; Algeria, Morocco, Tunisia and Libya (also known as North Africa countries with Egypt included). Mashreq countries include; Jordan, Lebanon, Syria, Iraq and Palestine (also known as Levant countries with Iraq excluded). GCC countries include; Bahrain, Oman, Kingdom of Saudi Arabia, United Arab Emirates, Qatar and Kuwait. Egypt is sometimes considered as Mashreq country or Maghreb country due to its centralized location between the two subgroups. Iran and Yemen are not included in any of the groups, yet, they are not grouped together but actively trade with the region as will be shown (Richter 2012: 1 , The World Bank 2010a: 1).

\section{Maghreb Sub-Region}

Maghreb countries represent $25 \%$ of MENA's total population with a GDP-share of approximately $33 \%$ of MENA's total GDP. Intra-Maghreb trade is the lowest among other sub-regions' intra-trade volume; it is estimated that the share of intra-Maghreb trade is less than $3 \%$ of total Maghreb's trade (Wynne 2008: 159, The World Bank 2010a: 8, Richter 2012: 3). Libya and Tunisia trade the most with each other in the subregion. The European Union (EU) is the largest trading partner to Maghreb countries, where on average 55\% of the sub-region's total imports are from the EU and $60 \%$ of its total exports are to the EU. $72 \%$ and $66 \%$ of Tunisia's and Morocco's exports respectively are 
manufactured goods, whereas, Libya's and Algeria's exports are mainly restricted to oil and gas. There exist also linkages between Maghreb countries and GCC countries captured mainly in Maghreb countries' export of tourism especially in Morocco (Burke \& Bazoobandi 2010:6). The low intra-Maghreb trade could be attributed to political tensions among the region's countries, where trade is hindered rather than facilitated. For instance, borders between Morocco and Algeria have been closed since 1994 over political disputes. Moreover, lack of transportation networks is another major reason for hindering trade in the region. In conclusion, Maghreb countries trade more with the EU than among themselves or the other sub-regions in MENA (Romagnoli \& Mengoni 2009: 72, Belhadj 2009: 2).

\section{Mashreq Sub-Region}

Mashreq countries represent $18 \%$ of MENA's total population with a GDP share of $8 \%$ of MENA's total GDP. Mashreq countries are not blessed with the merits of the oil wealth except for Iraq; nevertheless, they have an abundance of labor. Intra-Mashreq trade is the highest compared to the other sub-regions, representing $10.4 \%$ of its total exports Mashreq countries surpass the other two sub-regions in regional trade as well as in international trade (Romagnoli \& Mengoni 2009: 75). Syria, Jordan and Palestine are the most active trading partners among Mashreq countries. EU is also Mashreq's largest trading partner with an export share of $25 \%$ and an import share of $28 \%$. However, the importance of trade linkages with GCC countries as well cannot be overlooked as it represents $7 \%$ of Mashreq exports and $17 \%$ of imports. Based on the distribution of resources highlighted earlier, $50 \%$ of Mashreq imports from GCC countries are oil, whereas, exports from Mashreq countries to GCC countries mainly entail tourism and manufactured goods. From the GCC countries, Kuwait in specific is considered to be a major trading partner to Mashreq countries. Additionally, Mashreq countries trade with Maghreb countries with a conspicuously growing trend. For instance, Syria's and Jordan's exports to Morocco and Tunisia have been growing over the years (The World Bank 2010b: 5, Dervis et al. 1998: 4).

\section{GCC Sub-Region}

GCC countries represent $10 \%$ of MENA's total population with a GDP-share of $50 \%$ of MENA's total GDP. GCC countries are characterized with highincome levels and high economic dependency on oil. All GCC countries aim at diversifying their economic activities to reduce the high degree of dependency on oil, however, that aim hasn't been completely realized. Despite continuous efforts to free trade among GCC countries, intra-trade remains at low levels; lower than $10 \%$ (only $5 \%$ of exports and $6 \%$ of imports). Low levels of intra-trade could be attributed to the highdegree of similarity in their economic structure and natural endowments. Bahrain and Oman are the ones that trade the most with each other in the sub-region. GCC countries seem to be more integrated with the international world more than among them-selves. Once again, EU is a major trading partner and as has been previously highlighted Mashreq countries are important trading partners to GCC as well (Sturm \& Siegfried 2005: 11-16, Alkholiefy \& Alreshan 2010: 25).

Beside merchandise trade between GCC and other MENA sub-regions and in alignment with the goal of GCC countries to diversify their activities, GCC countries have been conducting investment projects in Maghreb and Mashreq countries. Investments in hydrocarbons, construction, manufacturing and financial services sectors are usually targeted by GCC countries. In Jordan, $50 \%$ of foreign investment is by GCC countries. The percentage is lower in Egypt reaching $33.3 \%$. Morocco is an attractive location for investment to GCC countries as well due to the availability of touristic places and the liberalization of its investment procedures. Despite these investment and diversification efforts, more than $50 \%$ of GCC investments are still limited to construction, tourism and recreational projects (shopping malls) (Burke \& Bazoobandi 2010: 5).

Overall, intra-MENA trade is considered to be very low $(5.9 \%$ in exports and $5.1 \%$ in imports from MENA's total trade). Intra-MENA trade represents a share of $3.5 \%$ from the region's total GDP, which also remains at a low level when compared to the share of regional trade in total GDP of other groups; EU (15.6\%), NAFTA and East Asia (26.5\%) (Richter 2012: 2, Romagnoli \& Mengoni 2009: 72, Krugman \& Obstfeld 2006: 564). It is argued though that the exclusion of oil-trade raises the level of intra-regional trade to reach almost $19 \%$. The MENA region as a whole trades more with the rest of the world, with the EU in specific than with itself as the pattern of sub-regions trade showed. However, numerous researches and empirical analyses based on gravity models have reached the conclusion that intraMENA trade is below its potential. Meanwhile, there is consensus on potential for improvements through tariff reductions (activation of trade agreements), removal of 
non-tariff barriers and improved transportation networks (Richter 2012: 2f).

On the other hand, it is argued that intra-MENA trade is not low when its markets' absorptive capacity is considered. It is not only intra trade that is very low, it is the total of MENA's trade compared to world trade that is low as well standing at $8 \%$ with oil-trade included and $3 \%$ when oil trade is excluded in 2005 (GoEurMed 2007: 2, Romagnoli \& Mengoni 2009: 71). Accordingly, it has been suggested that for the MENA region to become more economically integrated on a regional level, it must increase its economic integration on the international level first. International economic integration will induce economic growth and development in the MENA countries, where trading relations would encourage foreign investors to invest and relocate in the region. The attraction of foreign direct investment would promote economic growth that would enable individual countries to diversify their economic activities and act as an export hub for the rest of the countries in the MENA region; hence, intraregional trade is enhanced. This is of particular importance because even though MENA countries are diversified with respect to natural endowments, they are not able to achieve mutual benefits due to the lack of advanced production capacities that would substitute imports. This means that the domination of trade linkages of EU with MENA over intra-MENA trade could be used to foster intra-MENA trade. In addition, given the success of MENA's sub-regions in promoting intratrade compared to the region's intra-trade, it is argued that economic integration on the sub-region level could prelude the path for economic integration in the whole region (Romagnoli \& Mengoni 2009: 74, Fawzy 2002: 10, Saidi 2003: 6, De Silvia \& Jauregui 2004: 36).

\subsection{Similarity in Economic Structures}

It is expected that countries with similar economic structures are better qualified for the establishment of currency unions as they will be symmetrically affected by shocks. The symmetrical effect is particularly important in a currency union as a single monetary policy will be applied on all countries. Thus, if all countries are not affected in the same way, a one-size fits all monetary policy will not work, resulting in a negative impact on the union's sustainability. However, according to the European commission view, asymmetric shocks are reduced with the increase in economic integration. This implies that the establishment of monetary unions is not subject to the existence of symmetry in shocks, as economic integration that is enhanced through monetary integration reduces the frequency of asymmetric shocks. In addition, asymmetric shocks could be further mitigated by labour mobility and diversity of economic production by the union's member states (Laabas \& Limam 2002: 5ff, Ricci 1997: 33, Miles 2006: 412ff, Frankel \& Rose 1996: 4, De Grauwe 2003: 57, 83).

It has already been highlighted that MENA countries are diversified with respect to their natural endowments which directly affects their economic structures. The MENA region countries could be regrouped once again into three groups based on similarity in economic structure; Diversified and Mixed Economies (DME) (Algeria, Morocco, Tunisia, Syria, Jordan, Lebanon and Egypt), Oil-Rich Countries (ORC) (GCC, Libya, Iraq and Iran) and Primary Exports Economies (PEE) (Yemen). DME represent the North Africa and Levant sub-region identified earlier, where their economic activities encompass all the activities that have been generally specified earlier for the MENA region (agriculture, manufacture, oil extraction), nevertheless, despite the diversified nature of these economies they are still dominated by primary products. ORC focuses on oil extraction, whereas, PEE focuses on agriculture activities (Romagnoli \& Mengoni 2009: 75, El-Erian et al. 1996: 2).

This means that DMEs' diversified economies on the region level exposes it to the risk of asymmetric shocks, however, economic diversification on the individual country level mitigates this risk. Moreover, labor migration from North Africa and Levant countries could also mitigate the effect of asymmetric shocks. On the other hand, the lack of diversification in ORC and PEE reduces the risk of asymmetric shocks. This suggests that each individual sub-region on its own could be qualified for the formation of a currency union for their fulfillment of economic structure similarity and production diversity criteria as suggested by the OCA theory. However, it is important to note that the region as a whole is vulnerable to external shocks due to its dependency on the external world (El-Erian et al. 1996: 14).

\subsection{Labor Mobility}

The OCA theory stipulates that countries with higher labor mobility and higher wage flexibility are better candidates for a currency union with mitigation externalities in case of asymmetric shocks as previously argued. Labor mobility and wage flexibility are act as adjustment tools that replace the inability of 
countries' to change their exchange rates when an asymmetric shock strikes. With high labor mobility and wage flexibility, excess (shortage) in labor supply in one country compared to other countries in the union is absorbed (supplied) by deficit (surplus) countries creating a state of stability across the union (Laabas \& Limam 2002: 6, Ricci 1997: 33, Mundell 1961: 661, Miles 2006: 412ff, De Grauwe 2003:81f, Eichengreen 1991: 9).

In the MENA region, Labor movement is the more prevalent form of economic integration or even the origin of economic integration compared to intra-trade. Based on resource distribution, the MENA region could be regrouped into capital-rich countries (poor in labor) and labor-rich countries (poor in capital). The capital rich countries are the GCC countries with their oil wealth, while labor-rich countries are North Africa (Algeria, Morocco, Tunisia, and Egypt) and Levant countries (Jordan, Syria, Lebanon and Palestine) (GOEurMed 2007: 2, Saidi 2003: 6ff). The difference between these countries' resource endowments, income gap, geographical proximity, cultural similarities, historical ties and linguistic similarities facilitated migration from North Africa and Levant countries to GCC countries (Burke \& Bazoobandi 2010:78). Foreign labor in GCC countries like Qatar and UAE has reached as high as $80-90 \%$ (The World Bank 2010c: 3). Labor migration has been argued to be the only way through which MENA countries were able to benefit from GCC oil wealth. It has been estimated that around $66 \%$ of GCC's labor force of which $80 \%$ are professional and technical workers are from Egypt, Jordan, Yemen, Sudan and South Asia. From the MENA countries, immigrants from Egypt, Morocco, Lebanon, Jordan and Yemen are the highest. Remittances are a major and significant source of income for MENA countries, where Lebanon's share is the highest, reaching more than $50 \%$ of its remittances. (De Silvia \& Jauregui 2004:5, Willet et al. 2010: 1707, El-Erian et al. 1996: 7). Thus, labor migration is the main form of integration between GCC and the rest of the countries in the MENA region, especially Mashreq countries and Egypt (Romagnoli \& Mengoni 2009: 7677, The World Bank 2010c: 1, De Silvia \& Jauregui 2004:5, Burke \& Bazoobandi 2010: 8f, El-Erian et al. 1996: 2).

Although the high-degree of labor mobility implies that a currency union among MENA countries will not be highly exposed to the risk of asymmetric shocks as suggested by the OCA theory, labor movement in MENA is one-way only. Labor only moves from labor- abundant (poor) countries to labor scarce (rich) countries, hence the automatic adjustment tool for asymmetric shocks is only available for the poor countries, whereas, asymmetric shocks to rich countries will be hard to automatically adjust. This means that an asymmetric shock to rich countries will not only affect them negatively, it will rather affect the whole region due to their dependency on these countries as income resources (remittances). In other words, the region suffers from a problem of double dependency, whereby, poor countries are dependent on rich countries for income resources and the rich countries (oil exporting ones) are dependent on the rest of the world for oil prices, resulting in high economic vulnerability in the region. The economic vulnerability could only be mitigated with the existence of intra-trade that would be promoted through investment in poor countries as argued previously in order for the region to benefit from its diversity. Specifically, the investment by oil-rich countries in poor countries as adopted by GCC countries is of great importance to the development and economic integration of the region. These investments would create job opportunities in poor countries which would consequently reduce the effect of asymmetric shocks on rich countries in the region (GOEuroMed 2007: 6)

\subsection{Fiscal Integration and Political Unification}

Fiscal integration refers to the similarity and centralization of adopted fiscal policies which is almost non-existent except in GCC countries. Each country in the MENA region has its own rules and regulations with respect to budgetary controls, tax laws, and labor laws. The existence of fiscal integration is very crucial in the establishment and survival of a monetary union. Despite the loss of monetary policy independence, the lack of fiscal integration means that countries in a currency union still have complete fiscal policy independence which may affect the union's sustainability. It also ensures a state of balance in the union through the allocation of resources where poor economies are supported by richer ones as the case in the United States. Without fiscal integration, a one-size fits all monetary policy will be hard to manage (Krugman 2012, De Grauwe 2003: 58, Laabas \& Limam 2002: 7f, Ricci 1997: 33, Beetsma \& Giuliodori 2010: 616).

Arguably, all MENA countries aim at achieving economic development and prosperity through integration as evident by the various trade agreements that have been ratified. However, active enforcement of 
trade agreements with the rest of the world compared to passive and weak enforcement of trade agreements within the MENA region expose regional unification intentions to skepticism. It is argued that the loose commitment for regional unification is due to two main reasons; political tension in the region that depletes the resources of the countries as well as the lack of political commitment especially by Arab leaders who seem to fear the loss of their political sovereignty upon unification (Wynne 2008: 155, El-Erian et al. 1996: 27f, Fawzy 2002: 14f). Hence, the degree of political unification is very low as reflected in the level of political commitment exhibited by MENA countries.

\subsection{Status Quo of Economic and Currency Unions in the MENA Region}

The idea of economic or monetary integration is not a new one to the MENA region. There have been several trade agreements on the sub-regions level and among individual countries in the MENA region that aim at paving the path for economic or monetary integration through the elimination of trade barriers. Nevertheless, none of these trade agreements has covered the MENA region as a whole. For example, Tunisia, Morocco, Egypt and Jordan established trade affiliations under Agadir agreement in 2001. The agreement aims at promoting free trade among its countries as well as with the European Union. The agreement works in compliance with EU rules of trade and the World Trade Organization (WTO) rules as well. Promotion of free trade is expected to attract foreign direct investment as well (Dervis et al. 1998: 3). However, there has not been a substantial improvement in intra-trade among these countries or in other words, the agreement did not also fully realize its targets. Arab countries have also sought the liberalization of Arab trade zones and the creation of a common Arab market. The Arab league for example was formed in 1945 to serve these objectives. Also, GAFTA (Great Arab Free Trade Agreement) has been ratified in 1998, including all the Arab countries in the region (17 countries). Accordingly, there have been so many efforts to economically integrate the MENA region; however, none of these agreements has been able to fully realize their goals. The Arab Maghreb Union (AMU) and GCC are the most notably two relatively successful forms of economic integrations that aspire the establishment of monetary union (Richter 2012: 1).

The GCC countries escalated their level of commitment to the establishment of a monetary union by 2010. Numerous efforts have been exerted to achieve the economic, financial and fiscal convergence required for the formation of the monetary union, making the GCC countries even more converged when compared to EU countries before the establishment of the Euro-zone (Sturm \& Siegfried 2005: 32). All GCC members have reflected a high degree of commitment to the union, where all countries pegged their currencies to the US Dollar to achieve exchange rate stability that would enable them to adopt a common currency (Wynne 2008: 159). However, the establishment of the union was postponed without a reschedule due to the withdrawal of UAE and Oman from the prospect union. Results of previous studies are controversial, where some support the idea of a monetary union in the GCC and others oppose it based on OCA theory and empirical analyses, yet, efforts for integration have been praised. It is suggested that the GCC monetary union would constitute an OCA ex-post and not ex-ante. However, they all stress on the importance of political unification and more fiscal and economic integration among the countries. Researches even argue that the establishment of GCC monetary union would be a lot smoother than the establishment of the EU monetary union due to the high degree of similarity in their economic structures, relatively open economies, as well as the peg of their currencies to the US Dollar (Laabas \& Limam 2008: 31f, Wynne 2008: 155, Alkholiefy \& Alreshan 2010: 19).

\section{METHODOLOGY}

\subsection{Sample and Data Description}

The MENA region as specified earlier includes twenty countries. This study however encompasses only eleven of these countries. This is because Malta was excluded as it is already part of The Euro-zone. Djibouti was naturally excluded due to its weak relations with the region's countries. Palestine was excluded as well due to political instability and the vague role of legitimate institutions. Additionally, Bahrain, Lebanon, Libya, Oman, Qatar, United Arab Emirates were excluded due to the unavailability of data, namely; the incomplete data on unemployment rates from 1998-2008. Thus, the countries in the MENA region included in this study are; Algeria, Egypt, Iran, Iraq, Jordan, Kuwait, Morocco, Syria, Tunisia, Kingdom of Saudi Arabia and Yemen, i.e. a total of 11 countries.

All the data collected cover a time span of ten years; starting from 1998 to 2008 . That specific period was selected as it is relatively free of major economic 
turbulences/shocks in the MENA region or political events that may cause results to be misleading for merely seasonal effects. During that period, most of the countries were experiencing economic growth and stability that's reflective to these countries' real economic potential. The only exception is Iraq due to the American invasion that started in 2003 causing major economic instability (Burke \& Bazoobandi 2010: 2). On the other hand, the global effect of the 2008 financial crisis is not captured on purpose (time span ends in 2008) in order to avoid its economic repercussions on the economy of the countries under study. The two main sources for the data were IMF: Country World Economic Outlook Report, April 2012 and World Bank Databank; by country. All data are annual from 1998-2008.

The Taylor rule used in the stress analysis conducted in this paper is a monetary policy rule that has been developed by John Taylor. The rule was highly successful in fulfilling its primary objective; describing the US monetary policy. Ever since, it has gained wide popularity for its simplicity and its ability to not only describe the Federal Reserve's monetary policy but other central banks' monetary policy as well; such as Germany, Japan and the Euro area. (Woodford 2001: 232, Peersman \& Smets 1993: 86f, Osterholm 2005:221, Krugman 1996, Sauer \& Sturm 2007: 375). Taylor rule's main function is to guide the behavior of central banks on how to respond to inflation and output deviations from target (Carlin \& Soskice 2005:26f, Osterholm 2005:220, Krugman 1996, Sturm 2008:3). The rule specifically focuses on inflation deviation from target and the output deviation from potential output. As shown in equation (1), the rule states that a one percent increase in inflation rate $(\pi)$ compared to targeted inflation $\left(\pi^{*}\right)$ increases nominal short-term interest rates $(i)$ by more than one percent following a "tight" monetary policy. This indicates that a higher increase in short-term nominal interest rate compared to the inflation rate's increase encompassing the equilibrium real interest rate $(r r)$ is required to achieve economic stability on the short-run and reach targeted inflation on the long-run. The opposite applies in case of a one percent decrease in inflation rate; interest rates will have to be decreased by more than one percent following an "easy" monetary policy. The same applies when current output $(q)$ is higher than potential output $\left(q^{*}\right)$, interest rates have to be increased to restore the economy back to equilibrium and curb inflation (Sauer \& Sturm 2007: 379, Davig \& Leeper 2007: 607, Sturm \& Haan 2011: 48).

$$
i=r r+\pi+0.5\left(\pi-\pi^{*}\right)+0.5\left(q-q^{*}\right)
$$

The Taylor rule is used in this paper to calculate the short-term interest rates for the sample countries in the
MENA region and the area-wide interest rates to conduct the stress analysis as will be described in the following section. The utilization of the Taylor rule in the calculation of the short term nominal interest rates preassumes the adoption of the same monetary policy by all countries in the study. The calculated Taylor rates are used rather than the actual values of the nominal interest rates for each country to facilitate comparison.

The inflation rate was measured by the annual GDP deflator. It was collected from the World Bank databank for each country from 1998-2008.

Target inflation was set at $2 \%$ following Taylor's steps for all the countries over the 10-year time. Given that price stability is one of central banks' main concerns and based on the definition of price stability where inflation should no longer be a public concern; it has been proven that a target inflation of $4 \%$ or less fulfills this criteria. At the same time, it has been argued by Bernanke \& Mishkin (1997: 109ff) that target inflation should be more than zero for a number of reasons. First, usually there is inaccuracy in the measurement of inflation rates by the concerned authorities that lead to an overstatement of measured inflation rate by $0.5 \%-2 \%$ compared to the actual inflation rate (Clarida \& Gertler 1997: 368, Bernanke \& Mishkin 1997: 110). Thus, it is recommended that central banks' target for the measured rate of inflation should be more than zero to account for the wrong calculations. Second, setting the target inflation at zero percent exposes the economy to the risk of falling into a state of deflation leading to slow economic growth or contraction if persistent. In order to avoid the aforementioned risks, it is recommended that target inflation should be more than zero percent. Therefore, it can be concluded that target inflation should be more than zero percent and less than 4 percent, i.e. in the range of $1 \%-3 \%$. Accordingly, a target inflation rate of $2 \%$ is reasonable especially that in practice the official inflation target for Bundesbank has been set at $2 \%$ for a long time (Clarida et al. 1999: 1669).

Equilibrium real interest rate is defined as "the real rate of return that is required to keep the economy's output equal to potential output, which, in turn, is the level of output consistent with flexible prices and wages and constant markups in goods and labor markets" (Justiniano \& Primiceri 2010: 14). The equilibrium real interest rate varies from county to country and from one year to another, making its estimation a very difficult task (Arestis \& Chortareas 2006: 378, Laubach \& Williams 2003: 1063). Accordingly, based on the 
original Taylor rule and the conventional approach of setting the equilibrium real interest rate at $2 \%$ as adopted by Moons \& Poeck (2008: 194), the equilibrium real interest rate used in this study for all countries over the 10 years is $2 \%$.

The output gap is the difference between the current output and the potential output (Levine 2012:2). Generally, the calculation of the output gap is a complicated task mainly for the difficulty of calculating the potential output. Although, there are several proposed methods for the calculation of the output gap, none of them has gained wide acceptance among researchers (Arestis \& Chortareas 2006: 378). In this paper, Okun's law is followed for the calculation of the output gap. According to Okun's law, the output gap can be measured as the difference between current unemployment rate (current output) and the natural rate of unemployment (potential output). The stability and simplicity of Okun's law are the main reasons behind its popularity and its adoption in this paper (Mitchell \& Pearce 2010: 197f). Yet, it is important to highlight that the estimation of the natural rate of unemployment suffers from imprecision and the methods for its calculation are highly debatable (Staiger et al. 1997:196, Dobrescu et al. 2011: 184, Salemi 1999: 3f, Hall 1979: 154). Following Basistha \& Startz, (2008: 805) \& Staiger et al. (1997:209), the average rate of unemployment is used as an indicator to the Natural Rate of Unemployment in this study.

The potential output was fixed at the average of the rate of unemployment for each country from 19982008. The unemployment rates for each country under study from 1998-2008 were collected from the IMF: Economic Outlook Report April, 2012. Due to the incompleteness of unemployment rates for countries like Iraq, Kingdom of Saudi Arabia and Yemen, the unemployment rates were calculated using a proxy. The proxy was developed based on inverse the relation between economic growth and unemployment (Levine 2012:1). The availability of unemployment rates for two consecutive years for countries with incomplete data facilitated the calculation of the rate of change in unemployment rate and comparing it to the country's annual growth rate (as given by the World Bank databank for each country). Through this comparison, a ratio was calculated that indicates the percentage change in unemployment rate for each one percent change in annual growth rate. Based on the available data, the missing years were calculated using the proxy measure developed.
The weights on output and inflation deviation were equal; at 0.5 as developed by Taylor. The inexistence of a scientific ground for weight distribution is the main reason behind that. It is highly debatable whether they should be equal or one should be more heavily weighted than the other.

\subsection{Procedures}

The Taylor rule is used as a benchmark for the optimal interest rate of a central bank. Therefore, it can also be used to calculate the stress level which is the difference between the countries' independently set interest rate and the area-wide interest rate. In order to conduct the stress analysis, the procedures entail five steps that are described below in detail.

First, the annual short-term nominal interest rate has been calculated for each country from 1998-2008 using the Taylor rule (equation 2) and adopting all the assumptions presented in the previous section (Data Description) (Sauer \& Sturm 2007: 378, Basistha \& Startz 2008: 805);

$i_{c, t}=2 \%+\pi_{c, t}+0.5\left(\pi_{c, t}-2 \%\right)+0.5\left(\bar{U}_{c}-U_{c, t}\right)$

Where $i$ represents the Taylor interest rate, $\pi$ is Inflation rate measured by GDP deflator, $\bar{U}$ is the average unemployment rate (potential output), $U$ is the Unemployment rate (current output), $r r$ is the equilibrium real interest rate, set at $2 \%, \pi *$ represents the target inflation, set at $2 \%, c$ is Indicative to country (which country), $t$ - indicative to time (year)

Second, in order to identify potential currency unions i.e. countries with similar interest rates, an average of the calculated Taylor rates for each country were used. It is hypothesized that countries with similar interest rates will be able to form a currency union that is sustainable on the long-run (with low stress level).

Third, given that the proposed unions are hypothetical ones, hence, no area-wide interest rate is available; a calculation of the area-wide interest rate had to be conducted. The annual area-wide interest rate for each proposed union was calculated based on a weighted average of the union's countries Taylor rate. A weighted average is used to account for the fact that in a monetary union countries lose their monetary independence and usually interest rates are set to serve the interests of countries with high influence; economic and political influence (Sauer \& Sturm 2007: 380, Flaig \& Wollmershaeuser 2007: 16, Moons \& 
Poeck 2008: 194). Therefore, 2008 current GDP (in US dollars) was used as an indicator to the weight of each country in the proposed union. The annual area-wide interest rate for each proposed union was calculated using the following equation;

$\bar{l}_{u, t}=\sum W_{c} \cdot i_{c, t}$

Where $u$ is indicative to the union for which the interest rate is being calculated for and $t$ is indicative to the year for which the interest rate is being calculated for. W represents the weight of each country in the union using its GDP share in the total GDP of all countries in that union. $i$ represents the calculated Taylor rate for each country. $c$ as used earlier in the calculation of the Taylor rate is indicative to the country.

Fourth, the annual stress level which is defined as the difference in the annual interest rate between the country's Taylor rate and the annual area-wide interest rate is calculated. For each union, each country's annual Taylor rate is compared to the corresponding proposed union's area-wide interest rate using the country-specific stress rule presented below (Sturm \& Wollmershaeuser 2008: 5f);

$S_{c, t}=i_{c, t}-\bar{l}_{u, t}$

Where $S$ represents the country-specific stress level, $i_{c, t}$ represents the country's Taylor rate and $\bar{l}_{u, t}$ represents the area-wide Taylor rate.

Low stress level (degree of stress level will be measured using a stress indicator that is presented later on) indicates that the country's independently set interest rate is close to the proposed union's interest rate, hence, easier sustainable integration. On the other hand, a high stress level indicates difficulty in integration and sustainability due to the difference between the country's independently set interest rate and the proposed union's interest rate. The countryspecific stress level could be a positive or negative value; a positive stress indicates that the country follows a tight monetary policy compared to the proposed union, whereas, negative stress indicates that the country is following a loose/easy monetary policy compared to the proposed union (Sturm \& Wollmershaeuser 2008: 5f)

Fifth, two stress indicators are calculated to make a comparison among unions and a comparison among countries in a given union. The Root Mean Squared Country-specific stress (RMSC) is used as indicator to the stress level of countries in one union calculated as follows (Moons \& Poeck 2008: 196f);

$$
R M S C_{c}=\sqrt{\frac{\sum_{t=1}^{T}\left(i_{c, t}-\bar{l}_{u, t}\right)^{2}}{T}}
$$

$T$ represents the number of years

Whereas, Union Mean Stress (UMS) is used to compare among unions;

$U M S_{u}=\frac{\sum_{n=1}^{n} R M S C_{c}}{n}$

$\mathrm{n}$ represents the number of countries in a union.

\section{EMPIRICAL RESULTS AND THEIR INTERPRETATION}

\subsection{Empirical Results}

According to the procedures presented, the Taylor rates for each country in the sample are calculated at the beginning. Figure 1 provides a graphical representation of each country's calculated Taylor rates from 1998- 2008.

Iran's and Iraq's Taylor rates are observed to be the highest compared to the rest of the countries' Taylor rates. In the period from 1998-1999, the Taylor rates of KSA, Iran, Iraq, Kuwait and Algeria have sharply increased compared to the rest of the countries (Taylor rates of all countries have increased during that period as well). The sharp increase in Taylor rates is explained by acute increases in inflation rates of these countries as observed from the GDP deflators of each country. It is suggested that the increase in inflation rate could be attributed to the 1997 decrease in oil prices (all these countries are oil exporters) reaching a price of $\$ 11$ per barrel in 1999 , which resulted in import inflation due to their heavy reliance on imports from oilimporting countries like the EU.

On the other hand, a sharp decrease in Taylor rates has been observed in the period from 2000-2001 in KSA, Kuwait, Iran, Iraq and Algeria. The sharp decrease in inflation rates observed is argued to be the main factor behind the sharp decrease in the Taylor rates. Once again, oil prices play a very important role in explaining the sharp decrease in inflation whereby oil prices increased in 2000 reaching a price of $\$ 35$ per 

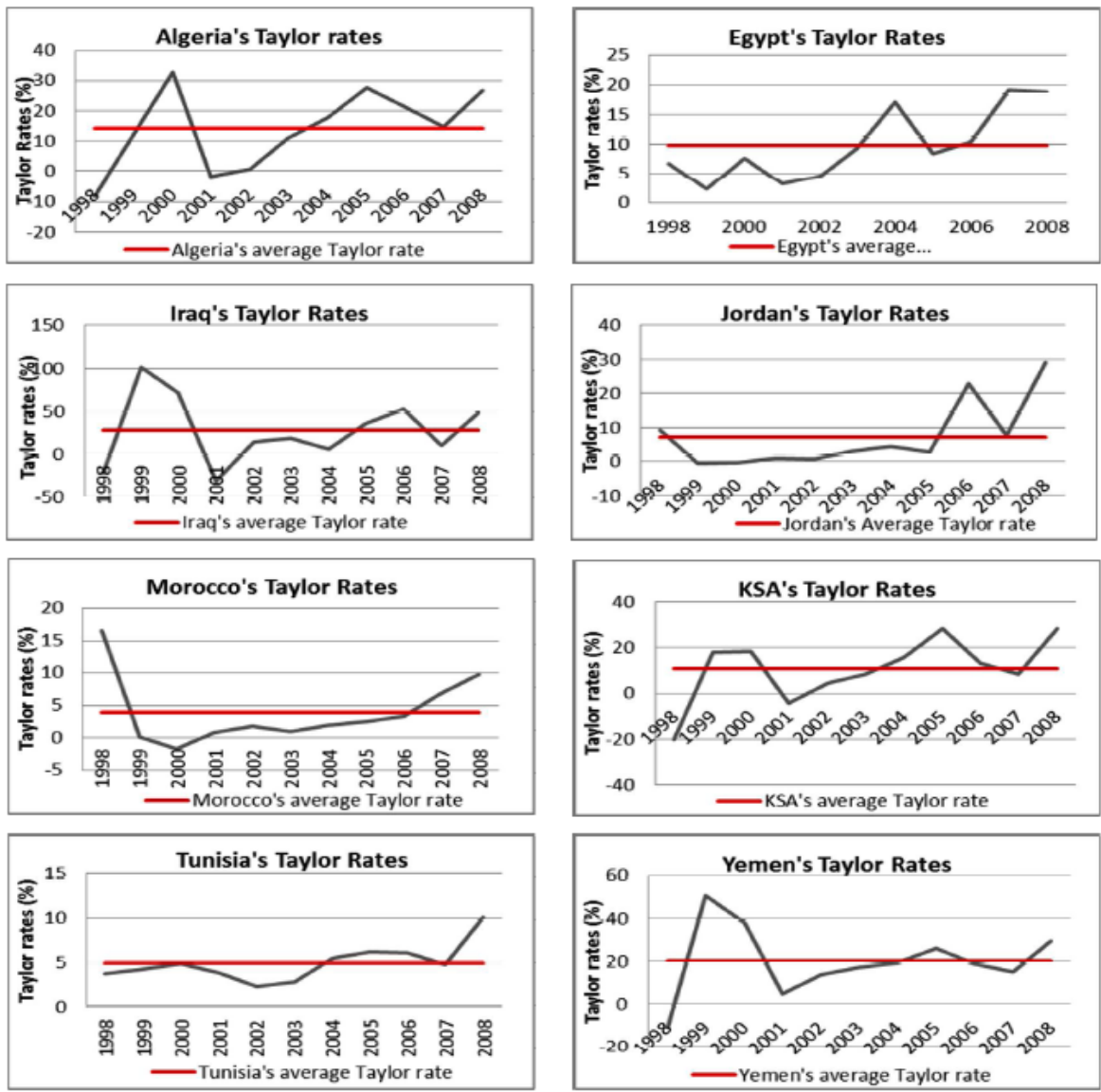
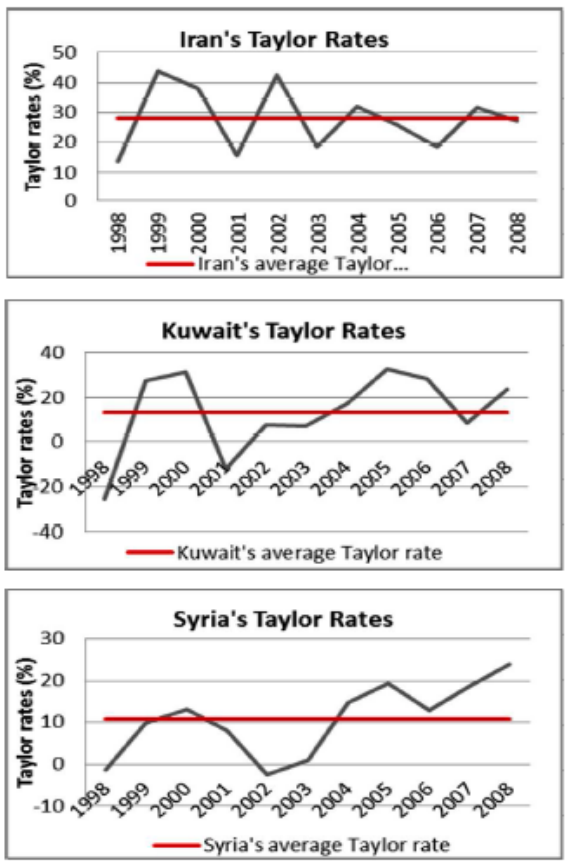

-Syria's average Taylor rate

Figure 1:

Table 1: Average Taylor Rate (Potential Unions)

\begin{tabular}{|c|c|c|}
\hline Countries & Average Taylor IR & Standard Deviation \\
\hline \hline Morocco & 3.94 & 2.26 \\
\hline Tunisia & 4.95 & 9.84 \\
\hline Jordan & 7.21 & 6.03 \\
\hline Egypt & 9.77 & 14.05 \\
\hline KSA & 10.71 & 8.71 \\
\hline Syria & 10.74 & 18.60 \\
\hline Kuwait & 13.24 & 13.053 \\
\hline Algeria & 14.13 & 16.29 \\
\hline Yemen & 20.24 & 39.46 \\
\hline Iraq & 27.53 & 10.67 \\
\hline Iran & 28.01 & \\
\hline
\end{tabular}

barrel. Accordingly, inflation significantly dropped (IMF 2000:1).

Additionally, it can be observed that Iran's Taylor rate on average is higher than all the countries' Taylor rates. Iran's higher than average Taylor rate is attributed to its persistently high inflation rate. Armesh et al. (2010: 30-37) and Habibi (2008:3) relate the high variable inflation rate of Iran to liquidity growth, government spending and economic policies adopted by President Ahmadi Nejad. In 1998, Iran's inflation rate was two times higher than the average inflation rate of other developing countries (Alizadeh 2003: 
270). This explains Iran's highly variable Taylor rates calculated. The high variation in Iraq's Taylor rates could be also attributed to the American invasion in 2003. Iraq's Taylor rates' standard deviation is extremely high (39.4) in absolute terms and when compared to other countries' Taylor rates' standard deviation.

According to the average of the calculated Taylor rates, countries fall into one of three uneven interest ranges; below $5 \%$, from $5 \%$ to $15 \%$ and above $15 \%$. Conspicuously, Morocco and Tunisia fall into the first range with average Taylor rates below $5 \%$, hence forming the first proposed union. Then, Jordan, Egypt, Kingdom of Saudi Arabia (KSA), Syria, Kuwait and Algeria qualify for the second proposed union with average Taylor rates ranging from $7.21 \%$ to $14.13 \%$. Finally, the third proposed union includes Yemen, Iraq and Iran with average Taylor rates above $15 \%$. Table 1 provides a summary of the average of the calculated Taylor rates for each country and their standard deviation.

In addition to proposed unions based on interest rates similarity, seven additional unions (country groupings) are proposed. The additional unions are proposed according to natural country groupings as discussed earlier under MENA countries section due to their geographic proximity or shared interests. This study focuses on the monetary similarity aspect among countries to qualify for the formation of currency unions, increasing the number of proposed unions based on scientific criteria will help in better identifying the more sustainable union on the long run. The subregions of the MENA region namely; Maghreb countries, Mashreq countries and GCC countries are among the first potential unions proposed based on the previously presented argument that they are more integrated, hence, are more qualified for further integration from the monetary aspect. Additionally, a North African union as well as a Middle Eastern one is proposed for their plausibility based on geographic proximity, cultural ties and trade relations. OPEC (Organization of the Petroleum Exporting Countries) as a potential union is also proposed based on the common shared interests' of its countries. Finally, a MENA wide union is proposed to cover the whole area and compare its sustainability to the sustainability of the sub-unions proposed.

As mentioned earlier, this study only includes eleven countries in the MENA region based on the availability of data. Thus, the additional unions proposed are not represented as per the definition mentioned, hence, the countries available in this study corresponding to the definition are only included. Accordingly, MENA union includes all the eleven countries in this study representing the MENA region. North Africa union is represented by Algeria, Egypt, Morocco and Tunisia. GCC union is represented by KSA and Kuwait only. Arab Maghreb Union is represented by Algeria, Morocco and Tunisia. OPEC union is represented by Algeria, Iran, Iraq, KSA, and Kuwait. Finally, Middle East union is represented by Egypt, Iran, Iraq, KSA, Kuwait, Jordan, Syria, and Yemen.

Based on the calculations of the country-specific stress using equation (4) and the stress indicators using equations (5) and (6), Figure 2 presents a graphical comparison between the proposed unions, where unions are sorted from smallest to largest according to the value of Union Mean Stress (UMS). This figure represents the final results of this study where potential unions are compared to reflect the degree of sustainability. As mentioned earlier, it is hypothesized that the lower the UMS, the more sustainable the union is.

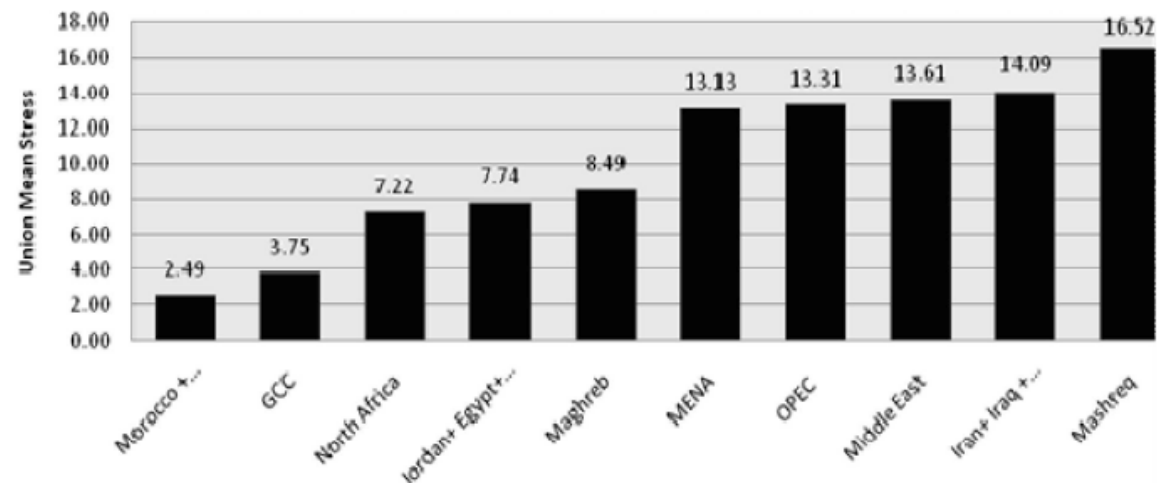

Figure 2: Union's Comparison (Sustainability of Potential Unions). 


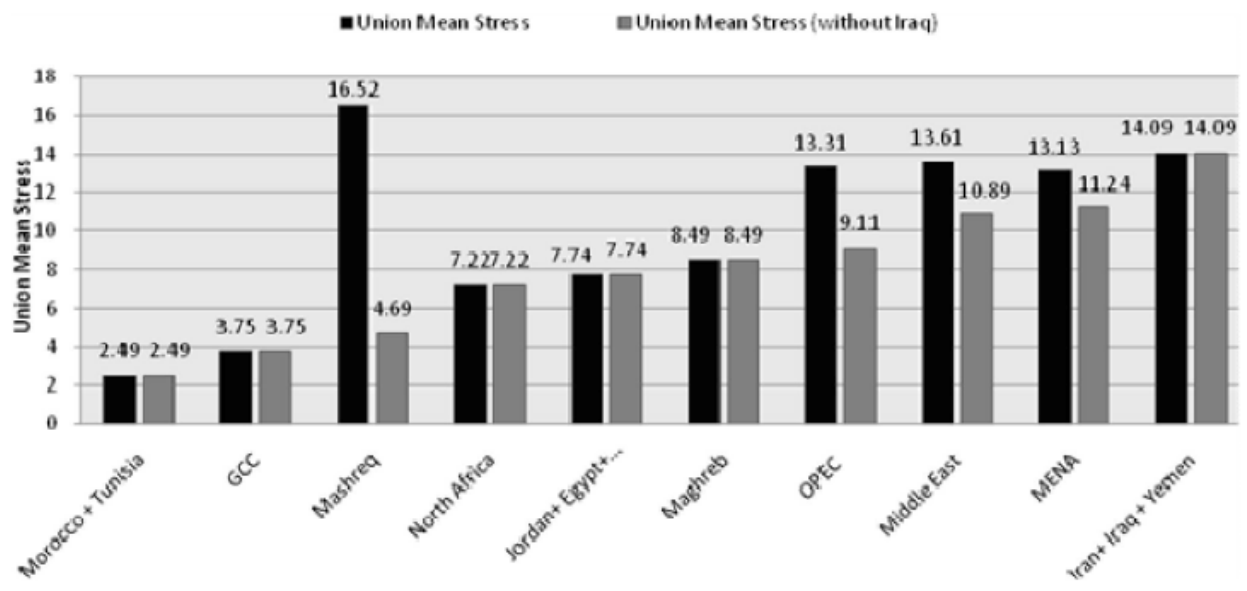

Figure 3: Union's Comparison without Iraq.

According to the results presented, Morocco and Tunisia union is the most sustainable potential union in the MENA region given its very low Union Mean Stress level. Meanwhile, Mashreq union (Iraq included) is the least sustainable potential union in the MENA region given its high Union Mean Stress level compared to all the other proposed unions in the region.

The GCC union could be also considered as a highly sustainable potential union as its Union Mean Stress level is as low as the Morocco and Tunisia union stress level. North Africa union, Jordan, Egypt, KSA, Syria, Kuwait and Algeria union and The Arab Maghreb union are characterized with an average Union Mean Stress level when compared to all the proposed union in the region, making their degree of sustainability as potential unions in the region a moderate one. However, despite these unions' moderate degree of sustainability among the proposed unions in the region; they are worth a considerable amount of attention given their potential for further economic integration among their countries.

The rest of the unions proposed namely; MENA union, OPEC union, Middle East union, Iraq, Iran and Yemen union and Mashreq are characterized with relatively high Union Mean Stress level. An interesting and surprising result prevails in the fact that the OPEC union and the Middle East union are less sustainable than the MENA union, although they are smaller unions in terms of the number of countries involved. The rationalization of this result will be explained under the "Economic Interpretation" section Contrary to expectations, the Mashreq union has the highest Union Mean Stress level which is highly attributed to inclusion of Iraq with its high and variable Taylor rates compared to the rest of the countries in the union. Hence, it is worthwhile excluding Iraq from all the unions given its highly unstable rates that lead to the distortion of results. Figure 3 presents unions' comparison without Iraq, it is clear that the exclusion of Iraq from the proposed unions reduces the union's mean stress level.

The exclusion of Iraq as previously discussed makes Mashreq union the third most sustainable union in the region. At the same time, Middle East union and OPEC union become more sustainable than the MENA union compared to the previous results (Iraq included).

\subsection{Economic Interpretation}

There are two main factors that affect the stress level in the proposed unions namely; degree of synchronization between these countries' macroeconomic variables (similarity in Taylor rates) and the power distribution among the countries in that union (GDP-weight). It has been hypothesized that the more similar the average Taylor rates of the countries in a union, the lower the stress level in the union is expected to be. Another factor that affects the stress level in the union is the distribution of power reflected in the calculation of the area-wide Taylor rate using GDPweighted average. For example, given that the MENA union includes all the countries in the region, it was expected to have the highest stress level among all unions proposed. Although, its stress level is among the highest in all the proposed union, yet, it didn't come last, it is the fifth least sustainable union (Iraq included) and the second least sustainable (Iraq excluded), and the reason behind that is explained hereafter.

KSA and Iran are the main two players in MENA union with a GDP-share of $29 \%$ and $21 \%$ respectively. 
These percentages don't make them dominating players; however, they are the largest in the union. These two approximately equal powers behave in opposite directions creating a sort of balance in the union where different interests are served through the area-wide Taylor rate. This is reflected in their average Taylor rates as KSA's average Taylor rate is $10.7 \%$, whereas, Iran's average Taylor rate is $28.01 \%$. KSA and Iran together represent $50 \%$ of the union's GDP; the remaining $50 \%$ are shared by 9 countries. The $50 \%$ are distributed as follows; Algeria 11\%, Egypt $10 \%$, Kuwait 9\%, Morocco 6\%, Iraq 5\%, Tunisia and Syria $3 \%$ each, Yemen $2 \%$ and Jordan $1 \%$. KSA is expected to be serving the interests of Algeria, Egypt, Kuwait, Jordan and Syria given the similarity in their average Taylor rates. At the same time, Iran's average Taylor rate is similar to Iraq and Yemen, hence, their interest are to be served through Iran. Morocco's and Tunisia's average Taylor rates are very low compared to KSA's and Iran's, thus, their interests may not be highly reflected.

This is evident through the stress indicators of Algeria (6.03), KSA (6.73), Kuwait (8.71), Syria (8.83), Egypt (11.37) and Jordan (15.00) which are relatively lower compared to the countries in the union. Also, Iran's stress indicator (15.36) is lower than Morocco's and Tunisia's stress indicators (17.33 and 13.79 respectively). However, contrary to the predictions is Iraq's high stress indicator (32.06) relative to Tunisia and Morocco. At the same time, Yemen's relatively very low stress indicator (9.22) was unexpected. In Iraq's case, it has already been presented that although Iraq's average Taylor rate is very similar to Iran's, yet its Taylor rates' standard deviation is very high leading to higher stress levels than expected. As for Yemen's case, a low stress indicator that is as low as KSA's. However, it seems that despite its negligible weight, it was able to benefit from the power distribution in this union. Yemen's average Taylor rate is $20.23 \%$, which is approximately double KSA's average Taylor rate and half Iran's average Taylor rate and with the influence of Algeria and Kuwait, the areawide Taylor rate by coincidence was reflective of Yemen's interests despite its small weight.

On the other hand, although, Iran, Iraq and Yemen union is composed of only three countries, it is the second least sustainable union. This is because of the high stress level caused by the unequal distribution of power and low degree of interest rates' similarity. Iran is the dominating country in that union with GDP-share of $75 \%$. Iraq has a GDP-share of $19 \%$, whilst, Yemen has a $6 \%$ GDP-share. Although, Iran and Iraq have similar interest rates and Iran is influencing the areawide Taylor rate in its favor, Iraq has the highest stress indicator due to its highly variable Taylor rate. Iran has the lowest stress indicator with a value of 6.83 , Yemen follows with a value of 9.67 and Iraq has the highest stress indicator with a value of 30.50 .

Practically, this union is hard to establish due to the high discrepancy between its countries' economic power as Iran's GDP 12 times higher than Yemen's GDP. In addition, there is high political tension between Iran and Iraq making the realization of such a union a very unrealistic matter. This means that any combination of these three countries will simply not work in the establishment of a sustainable union. In this case, calculating the average stress level without Iraq is in vain given the difficulties mentioned before, thus, the union's average stress level is not calculated with Iraq excluded.

As with respect to the Middle East Union, despite the smaller size of it compared to the MENA union, it has a slightly higher stress level. As explained earlier, this result could be traced to the divergence in MENA union's Taylor rates and the power of distribution. The high stress level (13.31) in the Middle East proposed union makes it the third least sustainable potential union in the region (Iraq included).

The sample of the Middle East union consists of eight countries, namely; Yemen, KSA, Kuwait, Syria, Jordan, Egypt, Iran and Iraq. KSA has the largest GDP in the region with a GDP-share of $36 \%$, yet, it is not the dominating country (share less than $50 \%$ ). Iran is the second largest country with a GDP-share of $26 \%$. Both countries represent $62 \%$ of the union's total GDP. The remaining six countries represent $38 \%$ of total GDP distributed as follows; Egypt 12\%, Kuwait 11\%, Iraq $7 \%$, Syria $4 \%$, Jordan and Yemen $2 \%$ each. The existence of divergent Taylor rates and the lack of a dominating country set the area-wide Taylor rate at an average value that highly serves Yemen's interests. Yemen has a relatively low stress indicator (7.78) that is very close to KSA's (7.57) which has the union's lowest stress level. Iraq's high stress indicator (30.73) is persistent in all unions. The stress indicators of Kuwait (8.45), Syria (10.43) and Egypt (13.00) are not exceptionally high as Iraq's. Iran's and Jordan's stress indicators are (14.28) and (16.59) respectively.

Iraq is the main source of stress in that union with its persistent high stress level. The exclusion of Iraq 
lowers the union's average stress level by 2.72 , resulting in a lower average stress level (10.89) compared to the MENA union with and without Iraq. The impact of Iraq's highly unstable Taylor rates was more prevailing in the smaller union (Middle East union) compared to the larger union (MENA union) as the distribution of power in the Middle East union is less diverse. Without Iraq, the Middle East union becomes more sustainable than the MENA union. This is an interesting result that transfers the Middle East union closer to the medium-average stress level unions' category. The same applies to the OPEC union that becomes more sustainable than the MENA union after the exclusion of Iraq. Although, the OPEC union remains the fourth least sustainable union, nevertheless, its stress level decreased by 4.2 points to reach 9.11 .

Regarding the three most sustainable unions based on their relatively low stress level; Morocco and Tunisia, GCC and Mashreq union, it could be argued that the establishment of these unions is also plausible from a qualitative perspective. The arguments presented below stipulate that the GCC union has the highest potential among all unions proposed followed by Mashreq union and Morocco and Tunisia union.

Morocco and Tunisia union is considered to be the least sustainable from a qualitative perspective despite the fact that it has the lowest stress level. This is because intra-trade between the two countries in the Maghreb sub-region is very low (Tunisia trades more with Libya) which is a sub-region that is generally characterized with a low level of intra-trade among other MENA's sub-regions as previously discussed. Both countries trade more with the EU than among themselves, although they are members in the AMU that aims at promoting economic integration. On the other hand, there seem to be little if any political tension between the two countries, thus the process of unification may not be such a hard one. In addition, the similarity in their Taylor rates is indicative to their harmonized monetary policies and macroeconomic conditions; both are characterized with low inflation rates as price stability is the main target for their central banks. Hence, it could be argued that a monetary union is feasible and sustainable on the long-run. In addition, the similarity in these countries' economic structures implies that the risk of asymmetric shock is minimized. Nevertheless, the low degree of economic integration between the two countries means that the gains of a monetary union such as price transparency and exchange rate stability will not be fully realized or substantial as a motivation for the establishment of the union. It could be argued though that a monetary union will promote further economic integration between the two countries. In addition, from a monetary aspect, the union's stress level in reality could be much lower given that Morocco will not necessarily have an influencing share of $66 \%$; mitigation and negotiations among the union's countries can result in a an area-wide interest rate that satisfies all parties and doesn't stress one on the expense of the other. Finally, unification will strengthen the position of both countries in the international world which could be a main motivator for the establishment of this union.

However, the establishment of a monetary union among the Mashreq unions is more plausible than Morroco and Tunisia union. That's due to the fact that intra-Mashreq trade is amongst the highest sub-region' intra-trade. Moreover, it is the most connected subregion to the rest of MENA's sub-regions; hence, its economic development will be a gain to the whole region. Historically, these countries didn't have any political tensions. Labor mobility is very low though, but that's mainly due to the underdevelopment in these countries that is expected to be promoted under a monetary union. In addition, the high degree of similarity in their economic structures implies that they will not be exposed to the risk of asymmetric shocks. All these countries' economies are mainly dependent on primary manufacturing and services exports. They are all oil-importing countries, thus, changes in oil prices will have the same effect on all of them. Therefore, Mashreq union could be even more plausible than the GCC union as it is more economically integrated. Nevertheless, the Mashreq countries are far from the degree of convergence in monetary and financial aspects achieved by GCC countries, which makes the GCC union more plausible in the short-run. Mashreq union could be established on the long-run when countries achieve a higher degree of convergence that would even enable them to reduce the stress level in the union. In addition, the current situation in Syria as well as the political reformation in Egypt suggests that such a union is better established in the future when there is stability.

The GCC monetary union could be considered as the next anticipated monetary union after the EU. The similarity among its countries economic structures as well as their unified strategic goals encompassed in diversification and development qualify them for the formation of a monetary union. In addition, the empirical results based on the sample countries show 
that the stress level of the union is relatively low, this enforces the argument for its establishment. The low stress level indicates that the countries will be able to operate smoothly under a unified monetary policy. In spite of all these qualifying criteria, the proposed GCC monetary union in 2010 was not realized for political consideration. If only GCC's leaders would value the collective gain of such a union in terms of economic and political power and greater prosperity and development for the region more than they value political sovereignty, the GCC monetary union would be a sustainable union in the region. The GCC union could provide larger gains for the MENA region as a form of sub-region integration when compared to the Morocco and Tunisia union given its tighter relation to the rest of the MENA sub-regions; the Mashreq in specific. Thus, the establishment of the GCC union is encouraged more. Finally, the GCC monetary union as a MENA sub-region is also expected to prelude the path for the establishment of a MENA-wide union in the future that would empower the region in the international world.

\section{CONCLUSION}

In conclusion, with unity comes power and a monetary union empowers its countries through a common currency that provides them with high economic and political bargaining powers. According to results, Morocco and Tunisia union was the most sustainable union as it had the lowest stress indicator. Mashreq union was the least sustainable union. However, after the exclusion of Iraq from the Mashreq union, Mashreq union becomes the third most sustainable union in the region and the Iran, Iraq and Yemen union becomes the least sustainable one.

Furthermore, qualitatively and quantitatively the GCC union and Mashreq union are presented as the most sustainable and plausible unions in the region from all the unions proposed in this paper. It is argued that the establishment of a monetary union on the subregion's levels suggested is the way towards a regionwide monetary union in the future. Although, Morocco and Tunisia union is the most sustainable according to empirical results, yet their currently low level of intratrade doesn't justify the establishment of a monetary union among its countries. GCC countries have already achieved a high degree of monetary and financial integration and plans for the establishment of a GCC currency union are ongoing. At the same time, Mashreq countries have the highest level of intra-trade in the MENA region and their economic structures are very similar which helps in reducing the effect of asymmetric shocks. However, the lack of economic and financial convergence in the Mashreq union suggests that GCC union is the first to be realized.

It is expected that the establishment of these unions will be highly resisted as currency unions are always challenged at the beginning as it was the case for the European currency union that took over two generations to be realized. Integration in the region is the only way for the region's development and empowerment of its countries. The main condition though for the success of the union that should be highly and continuously stressed on is the existence of political will and that's what MENA countries have to start with (Mundell 2000: 218, Cohen 2003: 280).

Finally, for further research purposes, it is recommended that a deeper analysis of the political linkages in the region should be addressed with a suggestion on how political disputes and fear of loss of sovereignty could be overcome. Another important aspect that should be analyzed is measures that MENA countries can adopt to effectively promote economic integration. Additionally, an analysis of monetary unions among MENA countries should be addressed with respect to the degree of the countries' business cycle synchronization that directly affects the degree of sustainability in the union. Moreover, methods for the quantification of currency unions' gains are also an important aspect in the promotion for currency unions that should be further developed. Last, the results of this study could be further improved by relaxing the assumptions adopted in the empirical analysis as presented under the data description section.

\section{REFERENCES}

Alesina, A., Barro, R. (2002). "Currency Unions." Quarterly Journal of Economics 117(2): 406-436. http://dx.doi.org/10.1162/003355302753650283

Alizadeh, P. (2003). "Iran's Quandary: Economic Reforms and the Structural Trap." The Brown Journal of World Affairs 4(2): 267-281.

AlKholifey, A., \& Alreshan, A. (2010). "GCC Monetary Union." Bank for International Settlements Communications: Switzerland.

Arestis, P., Chortareas, G. (2006). "Monetary Policy in the Euro Area." Journal of Post Keynesian Economics 28 (3): 371394.

http://dx.doi.org/10.2753/PKE0160-3477280301

Armesh, H., Salarzehi, H., Yaghoobi, N., Heydari, A. (2010). "Causes of Inflation in the Iranian Economy." International Review of Business Research Papers 6(3): 30 - 44.

Atesoglu, H. (2009). "Taylor and Keynesian Monetary Policy Rules." Journal of Post Keynesian Economics 31(3): 485-492. http://dx.doi.org/10.2753/PKE0160-3477310306 
Bacha, O. (2008). "A Common Currency Area for ASEAN? Issues and Feasibility." Applied Economics 40 (4): 515-529. http://dx.doi.org/10.1080/00036840600675653

Basistha, A., Startz, R. (2008). "Measuring the NAIRU with Reduced Uncertainty: A Multiple- Indicator Common-Cycle Approach." The Review of Economics and Statistics 90 (4): 805-811. http://dx.doi.org/10.1162/rest.90.4.805

Beetsma, R., Giuliodori, M. (2010). "The Macroeconomic Costs and Benefits of the EMU and Other Monetary Unions: An Overview of Recent Research." Journal of Economic Literature 48 (3): 603-641. http://dx.doi.org/10.1257/jel.48.3.603

Belhadj, A. (2009). "Heterogeneity of the Maghreb: The Results of Optimized Monetary Rules." Global Business and Management Research 1(3/4): 1-24.

Bernanke, B.S., Mishkin, F.S. (1997). "Inflation Targeting: A New Framework for Monetary Policy?" The Journal of Economic Perspectives 11 (2): 97-116. http://dx.doi.org/10.1257/jep.11.2.97

Burke, E., Bazoobandi, S. (2010). "The Gulf Takes Charge in the MENA Region." FRIDE's Working Papers, working paper no. 97

CIA, The World Fact Book. Central Intelligence Agency. Retrieved on 11.16.2012 from: https://www.cia.gov/library/publications/theworld factbook/rankorder/2001rank.html

Clarida, R., Gali, J., Gertler, M. (1999). "The Science of Monetary Policy: A New Keynesian Perspective." The Journal of Economic Literature 37 (4): 1661-1707. http://dx.doi.org/10.1257/jel.37.4.1661

Clarida, R., Gertler, M. (1997). "How the Bundesbank conducts Monetary Policy." Reducing Inflation: Motivation and Strategy: NBER, pp. $363-412$

Cohen, B.J. (2003). "Are Monetary Unions Inevitable?" International Studies Perspectives 4 (3): 275-292. http://dx.doi.org/10.1111/1528-3577.403004

Davig, T. \& Leeper, E. (2007). "Generalizing the Taylor Principle." The American Economic Review 97 (3): 607-635.

De Grauwe, P., Economics of Monetary Union. $5^{\text {th }}$ ed. Oxford University Press: New York; (2003).

De Silvia, S., Jauregui, C. (2004). "Migration and Trade in MENA: Problems or Solutions?" World Bank Working Paper Series, working paper no. 40.

Dervis, K., Bocock, P., Devlin, J. (1998). "Intraregional Trade among Arab Countries." Middle East Institute 52nd Annual Conference: Washington, DC

Dobrescu, M., Paicu, C., lacob, S. (2011). "The Natural Rate of Unemployment and its Implications for Economic Policy." Theoretical and Applied Economics 18 (2): 181-194.

Eichengreen, B. (1991). "Is Europe an Optimum Currency Area?" NBER Working Paper Series, working paper no. 3579.

El-Erian, M., Eken, S., Fennel, S., Chauffour, J. (1996). "Growth and Stability in the Middle East and North Africa." International Monetary Fund Publications.

Fawzy, S. (2002). "The Economics and Politics of Arab Economic Integration." The Egyptian Centre for Economic Studies Working Papers, working paper no. 66.

Flaig, G., Wollmershaeuser, T.(2007). "Does the Euro-Zone Diverge? A Stress Indicator for Analyzing Trends and Cycles in Real GDP and Inflation." CESIFO Working Paper Series, working paper no. 1937

Frankel, J., Rose, A. (1996). "The Endogeneity of the Optimum Currency Area Criteria." NBER Working Paper Series, working paper no. 5700 .

GOEuroMed (2007). "New Challenges: Regional Integration." GOEuroMEd Working Package Summary, working package no. 8
Habibi, N. (2008). "The Iranian Economy in the Shadow of Economic Sanctions." Crown Centre for Middle East Studies, Middle East Brief No. 31.

Hall, R.E. (1979). "A Theory of The Natural Unemployment Rate and the Duration of Employment." Journal of Monetary Economics 5 (2): 153-169. http://dx.doi.org/10.1016/0304-3932(79)90001-1

IMF (2000). "The Impact of Higher Oil Prices on the Global Economy." The International Monetary Fund

Justiniano, A., Primiceri, G. (2010). "Measuring the Equilibrium Real Interest Rate." Economic Perspectives 34 (1/2): 14-27.

Kenen, P. (1969). "The Optimum Currency Area: An Eclectic View." Monetary Problems of the International Economy, R. Mundell and A. Swoboda, University of Chicago Press: Chicago

Krugman, P. (1996). "Stable Prices and Fast Growth." The Economist.

Krugman, P. (2012). "Revenge of the Optimum Currency Area." The New York Times, 24-June

Krugman, P., Obstfeld, M. International Economics: Theory and Policy. $8^{\text {th }}$ international ed. Addison Wisely: Boston; 2006.

Laabas, B., Limam, I. (2002). "Are GCC Countries Ready for Currency Union?" Arab Planning Institute, Kuwait.

Laubach, T., Williams, J. (2003). "Measuring the Natural Rate of Interest." Review of Economics \& Statistics 85 (4): 10631070. http://dx.doi.org/10.1162/003465303772815934

Levine, L. (2012), Economic Growth and the Unemployment Rate. In: Congressional Research Service, Washington

Mckinnon, R. (1963). "Optimum Currency Areas." The American Economic Review 53 (4): 717-725.

Mckinnon, R. (2004). "Optimum currency Areas and the European Experience." Economics of Transition 10 (2): 343-364. http://dx.doi.org/10.1111/1468-0351.00115

Miles, W. (2006). "One Continent, One Currency? Varieties of Common Currency Experiences in Europe and Latin America." Kyklos59 (3): 411-426. http://dx.doi.org/10.1111/j.1467-6435.2006.00339.x

Mitchell, K., Pearce, D. (2010). "Do Wall Street economists believe in Okun's Law and the Taylor Rule?" Journal of Economics \& Finance 34 (2): 196-217. http://dx.doi.org/10.1007/s12197-009-9085-3

Moons, C. \& Poeck, A. (2008). "Does One Size Fit All? A Taylor-rule Based Analysis of Monetary Policy for Current and Future EMU Members." Applied Economics 40 (2): 193-199. http://dx.doi.org/10.1080/00036840600749763

Mundell, R. (2000). "Currency Areas, Exchange Rate Systems and International Monetary Reform." Journal of Applied Economics 3 (2): 217-256.

Mundell, R.A. (1961). "A Theory of Optimum Currency Areas." The American Economic Review 51 (4): 657-665.

Osterholm, P. (2005). "The Taylor Rule: A Spurious Regression?" Bulletin of Economic Research 57 (7): 0307-3378.

Peersman, G. \&Smets, F. (1999). "The Taylor Rule: A Useful Monetary Policy Benchmark for the Euro Area" International Finance 2 (1): 85-116.

Ricci, L.A. (1997). "A Model of an Optimum Currency Area." IMF Working Paper, working paper no. 76. http://dx.doi.org/10.5089/9781451849837.001

Richter, S. (2012). "Regional Trade Integration in the Middle East and North Africa: Lessons from Central Europe." Research Centre International Economics Policy Brief, policy brief no. 14

Rockoff, H. (2000). "How Long Did It Take the United States to Become an Optimal Currency Area?" NBER Working Paper Series, working paper no. 124 
Romagnoli, A., Mengoni, L. (2009). "The challenge of economic integration in the MENA region: from GAFTA and EU-MFTA to small scale Arab Unions." Economic Change \& Restructuring 42 (1/2): 69-83. http://dx.doi.org/10.1007/s10644-008-9058-0

Saidi, N. (2003). "Arab Economic Integration: An Awakening to Remove Barriers to Prosperity. ERF Working Paper Series, working paper no. 0322

Salemi, M.K. (1999). "Estimating the Natural Rate of Unemployment and testing the Natural Rate Hypothesis." Journal of Applied Econometrics 14 (1): 1-25. http://dx.doi.org/10.1002/(SICI)10991255(199901/02)14:1<1::AID-JAE495>3.0.CO;2-\#

Sauer, S. \& Sturm, J. (2007). "Using Taylor Rules to Understand European Central Bank Monetary Policy." German Economic Review 8 (3): 375-398. http://dx.doi.org/10.1111/j.1468-0475.2007.00413.x

Staiger, D.O., Stock, J.H., Watson, M.W. (1997). "How Precise Are Estimates of the Natural Rate of Unemployment?" Reducing Inflation: Motivation and Strategy: NBER, pp. 195 - 246

Sturm, J. Haan, J. (2011). "Does central bank communication really lead to better forecasts of policy decisions? New evidence based on a Taylor rule model for the ECB." Review of World Economics 147 (1): 41-58.
Sturm, J., Wollmershaeuser, T. (2008). "The Stress of Having A Single Monetary Policy in Europe." CESIFO Working Paper Series, working paper no. 2251

Sturm, M., Siegfried, N. (2005). "Regional Monetary Integration in the Member States of the Gulf Cooperation Council." Occasional Paper Series of the European Central Bank, occasional paper no. 31

The World Bank (2010a). "Economic Integration in the Maghreb." The World Bank, Washington

The World Bank (2010b). "Economic Integration in the Mashreq." The World Bank, Washington

The World Bank (2010c). "Economic Integration in the GCC." The World Bank, Washington.

Willett, T., Al-Barwani, K., El Hag, S. (2010). "The GCC's Fixed Exchange Rate: A Major Anomaly for OCA Analysis." The World Economy33 (12): 1702-1717. http://dx.doi.org/10.1111/j.1467-9701.2010.01301.x

Woodford, M. (2001). "The Taylor Rule and Optimal Monetary Policy" American Economic Review 91 (2): 232-237.

Wynne, L. (2008). "An Arab Union: Is regional economic cooperation the way forward for the oil states of the Middle East?" Cross Sections 4:151-162.

Received on 28-04-2014

\section{DOI: http://dx.doi.org/10.6000/1929-7092.2014.03.23}

(c) 2014 Mouchera Karara; Licensee Lifescience Global.

This is an open access article licensed under the terms of the Creative Commons Attribution Non-Commercial License (http://creativecommons.org/licenses/by-nc/3.0/) which permits unrestricted, non-commercial use, distribution and reproduction in any medium, provided the work is properly cited. 